\title{
Fostering Students' Speaking Ability through Traditional Talking Stick
}

\author{
Amallia Rizky Utami1), Bambang Yulianto'2), Ria Kamilah Agustina3) \\ 1), 2), 3) Universitas Hasyim Asy'ari, Tebuireng, Jombang, East Java, Indonesia \\ uameliarizky@gmail.com
}

\begin{abstract}
The research was about the effectiveness of Traditional Talking Stick to foster students' speaking ability on eight-grade of MTs Salafiyah Syafi'iyah in the 2018/2019 academic years. This study aimed to determine the effectiveness of the Traditional Talking Stick teaching method on students speaking abilities, before and after using the Traditional Talking Stick method. There were 36 students as samples in this study. Researchers used a quasi-experimental using 4-times pre-test and 4-times post-test design. The data of this study was collected from observation and speaking tests (pre-test and post-test). The data analysis was then performed using a T-test (paired simple test) facilitated by SPSS 16.0. The results of this study were (1) the average scores of students' pre-test on their speaking ability before using Traditional Talking Stick were 28,61 of pretest 1, 30,97 of pre-test 2, 33,92 of pre-test 3, 36,69 of pre-test 4-with all the of unsuccessful criteria. (2) The students' average scores of speaking ability after being taught using Traditional Talking Stick were 75,6 of post-test 1, 77,86 of post-test 2, 82,28 of post-test $3,84,89$ of post-test 4-with all of the success criteria. (3) The result of the students' average scores shown that there is a significant effect of the Traditional Talking Stick in students' speaking ability after-treatment. It is as explained from the gained of obtained pretest 4 and post-test 4 average scores, in which t-count is $-75,302$ (at $\mathrm{df}=35$ ) and $\mathrm{t}$ table $=2,03011$, which means that the result of the SPSS calculation has been successful.
\end{abstract}

Keywords: The Effectiveness, Speaking ability, Traditional Talking Stick

Citation APA Style: Utami, A. R., Yulianto, B., \& Agustina, R. K. (2020). Fostering students' Speaking Ability through Traditional Talking Stick. English Language in Focus (ELIF), 2(2), 71-78.

\section{INTRODUCTION}

$\mathrm{E}$ nglish is an international language spoken by many people in the world. Due to the popularity of English, some countries have placed English as their second language. This language then becomes very important in its use as a tool of communication and interaction with people around the world (Dewi,
Kultsum, \& Armadi, 2016). Besides, this language is also needed in many aspects of science, politics, economics, culture, technology, and especially education. In education, English is a very important subject because it is a way of unlocking knowledge in the world. Along with the importance of English as a communication tool, speaking skill is also 
very important. In practice, the listener will readily accept the information presented orally if the speaker can convey it accurately and correctly.

According to Nuraeni in Lawota (2018), speaking is the process of communicating information from the speaker to the audience to transform and enhance the knowledge, attitudes, and skills of the listener through the information received. It is a productive skill and cannot be separated from listening. This is in keeping with the scientific nature of communication, which consists of speakers, listeners, messages, and feedback. This statement means that when we talk, we produce meaningful text.

Speaking is a person's ability to articulate sounds/words for expressions, statements, to convey ideas, thoughts, and feelings (Zuhriyah, Agustina, \& Fajarina, 2018). Besides, speaking skill is also inseparable from the pronunciation, and teachers need to encourage students in learning English sounds (Brown as cited in Ananda, Sofian, \& Salam, 2017). However, referring to the reality, the good speaking skill becomes a difficult thing to achieve, especially for students in terms of the learning process in the classroom. There are many obstacles to why students find it difficult to improve their speaking skills. First, the majority of students assume that English teachers are not proficient in English. Second, students do not have a background in English. Third, students feel less confident in using English. In reality, most students find it difficult to speak even when they have a lot of vocabulary and have written well. The problem is students' fear of making mistakes. Fourth, the curriculum is not appropriate to help students improve their English language skills. In short, English is hard to learn because students are not motivated and meaningful learning strategies are discouraged. Thus the need for teaching strategies in which teachers help create a meaningful situation that encourages students to speak (Yolanda \& Hadi, 2019).

Given this problem, the Traditional Talking Stick learning model is assumed by researchers to become as an alternative solution where that play an important role in fostering speaking performance. The Traditional Talking Stick method is a method that uses a stick as a tool to give students a chance to speak up (Fitri, Sari, Eliyati, \& Aisyah, 2016). The Traditional Talking Stick was a method used by Native Americans, to let everyone speak their mind during a council meeting, a type of tribal meeting. According to the indigenous American tradition, the stick was imbued with spiritual qualities that called up the spirit of their ancestors to guide them in making good decisions. The stick ensured that all members, who wished to speak, had their ideas heard. All members of the circle were valued equally (Fujioka, 1988).

According to Laura in Saraswati (2016), Traditional Talking Stick is one of the techniques in the learning model in which teachers ask questions and students then answer questions by holding sticks. By implementing the method in the teaching and learning process, students will have the opportunity to express themselves. In line with promoting cooperative learning, Traditional Talking Stick learning model can enhance students 'ability to respect other students' opinions and provide 


\section{Utami, A. R., Yulianto, B., \& Agustina, R. K. (2020). Fostering students' Speaking ....}

opportunities for other students to express their ideas in groups (Arief, 2017; Cornelius-Ukpepi, Aglazor, \& Odey, 2016; Zakiah, Rosnija, \& Arifin, 2014). In sum, this study focuses on the effectiveness of Traditional Talking Stick to foster students speaking skills. In this study, the students' speaking ability would be focused on assessing speaking skills aspects, especially in comprehension, fluency, vocabularies, pronunciation, and grammar.

\section{RESEARCH METHODOLOGY}

$\mathrm{I}$ $\mathrm{n}$ this study, researchers used a quantitative study in terms of data collection and evaluation. Quantitative methods are a methodology that focuses on investigating postpositive statement for developing knowledge, using inquiry strategies such as experiments, surveys, and collecting data on predefined instruments to obtain certain statistical data (Sugiyono, 2011). Therefore, to find out the effectiveness of the Traditional Talking Stick on students' speaking skills, the researchers used a quasi-experimental design. The design used in this study is a one-time series. it uses only one group, an experimental group without a control group. Before doing the treatment, the experimental group was given a pretest. Then, the learning process will be treated using a Traditional Talking Stick method and subsequently post-test.

The population of this study is all students of the VII MTs Salafiyah Syafi'iyah Tebuireng in the academic year of 2018 / 2019. The sample of this study is the VIII $\mathrm{H}$ grade students in MTs Salafiyah Syafi'iyah Tebuireng, the academic year of $2018 / 2019$. The VIII H grade students consisted of 37 male students. To collect data in this study, researchers used tests (spoken test) and non-test methods (observation). The process used in the observation method is a direct observation sheet. This process aims to observe the teachers' and students' activities where the learning process is being carried out. In conducting the research, the main observers in the study are English language teachers of eighth-grade students at the Salafiyah Syafi'iyah Tebuireng and a collegestudent of the Faculty of Education Hasyim Asyari (as a sub-observer).

Besides observation, the other instrument used by researchers is the test. In simple terms, testing is defined as the method used to measure the efficiency, knowledge, intelligence, and ability of individuals or groups to collect data. The test instrument in this study is a speaking test-based freely topic that contains certain words that must be clearly and correctly pronounced. The students' fluency and confidence are also assessed to measure their pronunciation of particular words. This study will focus on all aspects of speaking comprehension. Meanwhile, a post-test will be given after implementation.

Besides, the teacher and students' observation data were analyzed using descriptive statistical analysis to determine the implementation of teaching and learning activities using a Traditional Talking Stick. Data analysis was done to gain insight into the implementation of each teaching and learning activity by public speaking. The pre-test question given by the researchers is about how they experience on their last year vacation. They answered it in 
English. Post-test is about their unique experiences. There is treatment implementation between before and after the test.

The completeness of learning outcomes is determined based on the MPG (Minimum Passing Grade) of recount text in second-semester students of MTs Salafiyah Syafi'iyah Tebuireng Jombang in the academic year 2018/2019. The MPG is 75. Lastly, in analyzing the data, the T-test was used to determine the difference between the average score before being given treatment (pre-test) with an average score after being given treatment (post-test) using the Traditional Talking Stick. In sum, the t-test is therefore used to find the final test results of the pretest and post-test (Sugiyono, 2009). If the results do not meet the t-test, the researchers use another method of assessment.

\section{FINDING AND DISCUSSION}

\section{he students' speaking ability
before Traditional Talking Stick
was applied}

In this study the researchers conducted several pretests on assessing how far the level of speaking ability in VIII $\mathrm{H}$ grade students before and finding out how the circumstances of students in speaking ability. Pre-tests were given at the first meeting to experimental groups VIII H to measure the students' prior achievement before doing the treatment. Next is a description of the research results on the effectiveness of Traditional Talking Sticks English speaking ability of the VIII $\mathrm{H}$ grade students in MTs Salfiyah Syafi'iyah Tebuireng. In the first and second pretest, they only want to speak Indonesian and did not want to use vocabulary in English.
Then in the third and the fourth pretest, some students already wanted to use English even though the mixed with Indonesian.

So there is a slight increase in the pretest. From the first, 2 times of pretest to the last 2 times of pretest terms of processing vocabulary. It can be ensured they will able to speak and process the sentence more easily. Then, some of them also have low vocabulary skills but they can be very fluent in their comprehensive abilities and very clear in explaining what will be spoken in Indonesian. Their ability to speak is very high. In the results of the 4 times pretest that has been given not all their results and speaking ability are low from the many aspects. The researchers found there was a problem. The lowest score of the first pretest result was 25 and the highest score was 34 , on the average of 28,61 . The lowest score of the second pretest result was 28 and the highest score was 37 , on the average of 30,97 . The lowest score of the third pretest was 31 and the highest score was 38, on the average of 33,92. The lowest score of the fourth pretest was 34 and the highest score was 40 , on the average of 36,69 . The result indicates that speaking ability in Islamic Junior High School of VIII H grade students at MTs Salafiyah Syafi'iyah Tebuireng is extremely low.

\section{The students' speaking after Traditional Talking Stick was applied} In this study, the researchers found good results after being given two times of treatments and assessment about how far the VIII H grade students' speaking ability after giving the treatment of the Traditional Talking Stick. The researchers have taught more than once so that the 


\section{Utami, A. R., Yulianto, B., \& Agustina, R. K. (2020). Fostering students' Speaking ....}

treatment of the Traditional Talking Stick method had a very good effect on their English speaking ability. For students who are not confident at first, they would be trained and be confident in speaking English. Their ability had been changed or been different from the initial test (pretest).

Referring to the normal increase of the first to the fourth post-test, it can be said that the Traditional Talking Stick method has great effectiveness and on students' achievement. Besides, the grammar and the vocabulary used also shown success. This result is evident from the way they convey and tell the recount text well, they have trained the bishop well and some are very fluent. There were only a few students (approximately four or five students) who were lacking in the first and second post-test results. The results of the first post-test showed that some students had increased the standard value (MMC), 75 and 75.06, out of a total of 36 students. The second post-test also showed a change of increase in the average value of 77.86 . While the highest score of the third post-test was 82.28 and the last was the average score of all students in the fourth post-test was 84.89.

Table 1. Descriptive Statistics on Pretest Score

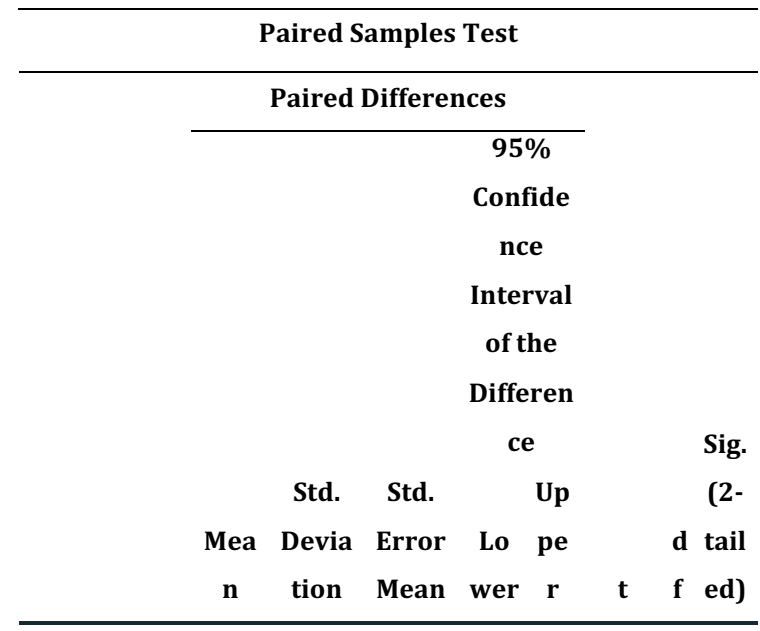

\begin{tabular}{|c|c|c|c|c|c|c|c|c|c|}
\hline Pair & prete & - & 3.358 & .5597 & - & - & - & 3 & .00 \\
\hline \multirow[t]{4}{*}{1} & st1 - & 46.4 & 36 & 3 & 47. & 45. & 82.9 & 5 & 0 \\
\hline & post- & 166 & & & 55 & 28 & 27 & & \\
\hline & test1 & 7 & & & 29 & 03 & & & \\
\hline & & & & & 7 & 6 & & & \\
\hline Pair & prete & - & 3.043 & .5073 & - & - & - & 3 & .00 \\
\hline \multirow[t]{4}{*}{2} & st2 - & 46.8 & 99 & 3 & 47. & 45. & 92.3 & 5 & 0 \\
\hline & post- & 611 & & & 89 & 83 & 68 & & \\
\hline & test2 & 1 & & & 10 & 11 & & & \\
\hline & & & & & 5 & 7 & & & \\
\hline Pair & prete & - & 2.948 & .4914 & - & - & - & 3 & .00 \\
\hline \multirow[t]{4}{*}{3} & st3 - & 48.3 & 63 & 4 & 49. & 47. & 98.4 & 5 & 0 \\
\hline & post- & 611 & & & 35 & 36 & 07 & & \\
\hline & test3 & 1 & & & 87 & 34 & & & \\
\hline & & & & & 9 & 4 & & & \\
\hline Pair & prete & - & 3.727 & .6212 & - & - & - & 3 & .00 \\
\hline \multirow[t]{4}{*}{4} & st4 - & 46.7 & 21 & 0 & 48. & 45. & 75.3 & 5 & 0 \\
\hline & post- & 777 & & & 03 & 51 & 02 & & \\
\hline & test4 & 8 & & & 88 & 66 & & & \\
\hline & & & & & 8 & 7 & & & \\
\hline
\end{tabular}

From the results of the above calculations, it can be seen that the results of a paired a simple $t$-test is significant because it produced a significant value of 0.00 that was less than the significant level of 0.05 , where it can be seen through the difference in $t$-cont values of each pretest. The pretest and the first Post-test were $\mathrm{t}-82,927$. The second pretest and post-test results were $\mathrm{t}-92,386$. Then the third pretest and post-test results were a t-test of $-98,407$. Lastly, the fourth pretest and post-test were $-75,302$. So that from the above data, it can be concluded that the $t$ value above shows the level of effectiveness because after comparing the SPSS results with t table,

It is found that $\mathrm{df}=35$ shows $\mathrm{t}$ table $=2,03011$ this means that the result of SPSS calculation has been successful even though SPSS the $t$ value calculated in SPSS indicates negative $(-)$ that can be interpreted as (+). Even though the value of $t$ in negative SPSS can be interpreted 
positively. It also seen from sigma test or value as it is known that $p$-value $<$ alpha, it means there is an effect/effective. This research also shows that the $\mathrm{p}$-value is 0,00 which means less than 0,05 . Thus concludes that $0,00<0,05$ it means this research sigma/p-value is effective.

\section{CONCLUSION}

$\mathrm{B}$ ased on the research finding, it is concluded that the implementation of Traditional Talking Stick is effective. It can be seen based on the percentage scores of students' achievements result in two meetings. The students' percentage score in the first meeting was $90 \%$ and the second meeting was $94 \%$, both in very good criteria. In addition, the student's speaking achievement also influenced the value of every element of speaking instrument rubric (grammar, fluency, vocabulary, pronunciation, and understanding), which is very good and significant comparing to the pretest stage.

In the pretest stage, the speaking achievement of students before being taught by Traditional Talking Stick was very low and incomplete. It is proved by the result of the pre-test and post-test per learning indicator data. Based on the SPSS calculation result, the overall students' scores were 38.3 (pre-test) and 84.89 (post-test). The results can be indicated that the Traditional Talking Stick method is effective in fostering students' speaking ability, particularly at the VIII $\mathrm{H}$ grade students in MTs Salfiyah Syafi'iyah Tebuireng.

\section{REFERENCES}

Ananda, E., Sofian, \& Salam, U. (2017). Improving Students' Speaking
Performance by Using Talking Stick Method. Jurnal Pendidikan dan Pembelajaran Untan, 6(8), 2-11. Retrieved from http://jurnal.untan.ac.id

Arief, H. (2017). The Effectiveness of Talking Stick Method in Teaching Vocabulary at the Second Grade of MTs Madani Pao-Pao. Undergraduate (S1) thesis, Universitas Islam Negeri Makassar. Retrieved from http://repositori.uinalauddin.ac.id/7784/

Cornelius-Ukpepi, B. U., Aglazor, G. N., \& Odey, C. O. (2016). Cooperative Learning Strategy: Tool for Classroom Management at the Basic Level of Education in Cross River State, Nigeria. In Proceedings of the iSTEAMS Multidisciplinary Cross Border Conference. University of Professional Studies, Accra Ghana. Retrieved from https://www.researchgate.net/publ ication/324779885

Dewi, R. S., Kultsum, U., \& Armadi, A. (2016). Using Communicative Games in Improving Students' Speaking Skills. English Language Teaching (ELT), 10(1), 63. https://doi.org/10.5539/elt.v10n1p 63

Fitri, M., Sari, W. V., Eliyati, \& Aisyah, N. (2016). The Effect of Applying Talking Chips Technique on the Students' Achievement in Speaking Ability. Proceedings of ISELT FBS Universitas Negeri Padang, 4(2), 6267. Retrieved from http://ejournal.unp.ac.id/index.php /selt/article/view/6962

Fujioka, K. (1988). The Talking Stick: An American Indian Tradition in the ESL 
Classroom (TESL/TEFL). The Internet TESL Journal, 4(9). Retrieved from

http://iteslj.org/Techniques/Fujiok a-TalkingStick.html

Lawota, Y. (2018). Penerapan Teknik Cerita Berantai untuk Meningkatkan Keterampilan Berbicara pada Siswa Kelas IV SD Inpres Nangameting. AtTadbir: Jurnal Manajemen Pendidikan Islam, 2(2), 39-51. Retrieved from https://doi.org/10.3454/attadbir.v2i2.3128

Saraswati, A. A. (2016). Using Talking Stick Method to Improve Students' Reading Mastery at the Second Grade Students of SMPN 1 PRINGAPUS in the Academic Year of 2016/2017. Undergraduate (S1) thesis, IAIN Salatiga. Retrieved from http://erepository.perpus.iainsalatiga.ac.id/ $1513 /$

Sugiyono. (2009). Statistika untuk Penelitian. Bandung: Alfabeta.
Sugiyono. (2011). Metode Penelitian Pendidikan: Pendekatan Kuantitatif, Kualitatif dan R\&D. Bandung : Alfabeta.

Yolanda, D., \& Hadi, M. S. (2019). Using Puppet Games in Teaching Speaking for Tenth Graders of Senior High School. English Language in Focus (ELIF), 2(1), 1-8. Retrieved from https://jurnal.umj.ac.id/index.php/ ELIF/article/view/4824

Zakiah, Rosnija, E., \& Arifin, Z. (2014). Improving Students Speaking Frequency Through Talking Stick. Jurnal Pendidikan Dan Pembelajaran Untan, 3(3), 214711. Retrieved from http://jurnal.untan.ac.id

Zuhriyah, M., Agustina, R. K., \& Fajarina, M. (2018). The Influence of Students' Creativity to Construct Sentences toward Their Speaking Skill. Register Journal, 11(1), 1-18. https://doi.org/10.18326/rgt.v11i1. $1-18$ 
English Language in Focus (ELIF), 2(2), 71-78. https://jurnal.umjj.ac.idd/index.php/ELIF 